\title{
Cooperating Teachers' Feedback on the Self- Evaluated Soft Skills of Pre-Service Teachers
}

\author{
*Raphael Job R. Asuncion, Don Mariano Marcos Memorial State University, Philippines, \\ rjasuncion@dmmmsu.edu.ph, ORCID: 0000-0002-6481-042X \\ Zita D. Ballesteros, Don Mariano Marcos Memorial State University, Philippines, \\ zballesteros@dmmmsu.edu.ph, ORCID: 0000-0001-9643-9816
}

\begin{abstract}
Soft skills of pre-service teachers during practice teaching (internship) in the cooperating schools are imperative, yet, none is known on their specific soft skills observed and reported by cooperating teachers (CT). This paper sought to provide information on the difference of the selfevaluated soft skills of pre-service $(\mathrm{N}=147)$ and their soft skills observed by $\mathrm{CT} \quad(\mathrm{N}=125)$ through convergent parallel mixed-methods design. Findings indicate that the most active self-evaluated soft skill of pre-service teachers is interpersonal skills, and the weakest is creativity and innovation. In contrast, the most observable soft skill by CT is Leadership skills, while interpersonal skill is the least observed. Furthermore, there is a significant difference in communication skills, critical thinking and problemsolving, lifelong learning, and management of information skills and interpersonal skills as to the preservice teacher's self-evaluation and CT's observation of their soft skills through a Wilcoxon matchedpairs signed-rank test.
\end{abstract}

Keywords: Soft skills, pre-service teachers, cooperating teachers, feedback, interpersonal, communicative skills, critical thinking and problem-solving

Received: 02.11.2020 Accepted: 15.12.2020

Published: 08.01.2021

\section{INTRODUCTION}

Pre-service teachers, as future catalysts in the reformation of the educational system, acquire hard skills for the teaching profession. According to Andrews \& Higson (2008), hard skills are the factual, technical, or disciplinary knowledge required for the job. For teacher education students, lesson planning, drafting tests, and making instructional materials are some of the hard skills they need to learn in the university. Nevertheless, acquiring technical skills alone does not equip graduates enough to become ready from the complexities of the workplace culture (Sharma \& Sharma, 2010).

Consequently, pre-service teachers might overlook social and behavioral skills or commonly known as "soft skills." Some researchers dubbed soft skills as personal attributes that can bring about latent growth and relationship with others. Some studies named it applied skills, intangible skills, nontechnical skills, personality-specific skills, relational skills, and 21st-century skills (Bailly \& Léné, 2013; Casner-Lotto \& Barrington, 2006; Gewertz, 2007; Robles, 2012). Moreover, teamwork, communication, and ethical behaviors are likely to be equivalent to the soft skills of an individual (James \& James, 2004). Yet, authors of different research studies have no consensus on the exact definition of soft skills concerning different settings such as race, culture, and organizations.

Such definitions of soft skills are eminent in the influence of universities on their graduates. Universities develop students' soft skills through college experience in coursework, group tasks, assessments, self-reports, and paper and pencil tests (Schulz, 2008). Whitehurst (2016) posited that soft skills are explicit and socially and contextually influenced and supported by classrooms. He further argued that soft skills are extensively a responsibility of schools. Old-fashioned pedagogy and university curriculum are not in effect in the soft skill development of students (Tran, 2013).

Similarly, professors and teachers affect students considerably on their soft skills (Osman et al., 2012). They have crucial implications in their teaching roles on students' learning experience of soft skills, particularly the accentuation on subject-specific knowledge and skills, and the impact of whatever the teacher's views on delivery(Osman et al., 2012; Schulz, 2008). Whereas, a wide range of circumstances develop the soft skills of students continuously (Waterhouse \& Virgona, 2004) through observation and experience (Osman et al., 2012) such as in the family, community, and workplace. This reason convinces some educators that soft skill development is more of a student's responsibility and that students control their learning (Osman et al., 2012). In such cases, pre-service teachers learned and acquired soft skills in the university before their internship. 
Increasingly, the labor market's feedback emphasizes that graduates must have soft skills, which empowers them to become professionally efficacious in the organization (Mitchell et al., 2010; Robles, 2012). Employers' feedback indicates a preference for technically proficient graduates and have interpersonal skills (Beard et al., 2008). Other feedback also favors punctuality, loyalty, and discipline (Grugulis \& Vincent, 2009), communication skills, and teamwork (Bee \& Hie, 2015), flexibility, critical thinking, and problem-solving(Nida'a \& Worley, 2018). However, employers are remarking that the current workforce oversights some essential soft skills, such as communication and interpersonal skills (Meeks \& Meeks, 2017). Similarly, the younger workforce, which comprises mainly of millennials, lacks leadership skills (Rao, 2018).

For teacher hiring, soft skills such as communication skills and personal qualities are evaluated in the hiring process. Both hard and soft skills are necessary for the internship known as Practice Teaching, a zenith of teacher training of a future teacher in which they have to do their internship to different schools (cooperating schools) in the region. Cooperating Teachers (CT) of different cooperating schools are responsible for mentoring the pre-service teachers in polishing their hard skills, looking into the soft skills of the pre-service teachers, and probably becoming the co-worker of the pre-service teachers in the future.

Although there are pieces of literature on feedback on soft skills, these are mainly studies on the employer's evaluation of the soft skills of applicants or employees in the workplace, conducted soft skills identification and assessment in the various professional fields, and piloted intervention programs for the soft skills enhancement. Many studies also include different variables on soft skills and university-related evaluation of soft skills to their students. The unavailability of accurate information on the universityindustry partnership to provide feedback on students' soft skills who attend an internship in industry encourages the importance of conducting this research. Following these reflections, there is a need for studies examining the soft skills of the pre-service teachers who are under internship and be given validation and verification of their soft skills by the cooperating teachers who are prospective co-workers. Therefore, the school-to-work transition should be given attention to understand the soft skills of the preservice teachers molded by universities and close the gap in the feedback of the industry.

Based on this background, the conduct of this research is within the context of shedding light on the self-evaluated soft skills of the pre-service teachers and the validation or verification of CT through the feedback of these soft skills by observation during the pre-service teachers' practice teaching. Specifically, the following are the objectives of the study: 1.) determine the self-evaluated soft skills of the pre-service teachers; 2 .) identify the observed soft skills of the pre-service teachers by the cooperating teachers; 3 .) investigate the significant difference between the self-evaluated soft skills of the pre-service teachers and the observed soft skills of the pre-service teachers by the cooperating teachers

\section{METHODS}

This study made use of a convergent parallel, a mixed-methods design. In this study, the researchers collected both quantitative (questionnaire) and qualitative data (unstructured interview and unrestricted essay), analyzed independently, and linked the outcomes for conformity or disconformity of findings (Creswell \& Creswell, 2018). This research used the symbol (QUAL+QUAN) by(Morse, 1991) as a basis.

\section{The population of the study}

The study included one hundred forty-seven (147) Bachelor of Elementary Education pre-service teachers majoring in general education of Don Mariano Marcos Memorial State University-South La Union Campus (DMMMSU-SLUC) in La Union, Philippines. These pre-service teachers are deployed for practice teaching in two provinces - La Union and Pangasinan. Of the 147 pre-service teachers, $114(78 \%)$ are females, whereas $33(22 \%)$ are males. 85 (58\%) pre-service teachers are deployed in Pangasinan province schools, while $62(42 \%)$ are deployed in La Union province. The total enumeration of the preservice teachers participates both in the quantitative part of the study (survey) and in the qualitative component (unrestricted essay) before they are deployed in their cooperating schools.

One hundred twenty-five (125) CTs are also part of the quantitative study. They are teachers with at least seven years of service and are of high position in the teaching profession and who mentored at least one pre-service teacher. Of 125 CTs, $95(76 \%)$ are females, while $30(24 \%)$ are males. $70(56 \%)$ CTs are from Pangasinan province, while 55(44\%) CTs are from La Union province. Purposive sampling was used in selecting the 27 CTs who were individually interviewed (21.6\% of the CTs' population) as part of the qualitative portion of the study. 


\section{Data Instrumentation and Gathering}

For pre-service teachers, the quantitative portion of this study adapted a survey questionnaire on selfevaluated soft skills from the study of Nikitina \& Furuoka (2012). This survey questionnaire was modified to fit for pre-service teachers. It consists of 43 questions. The first part of the survey questionnaire consisted of the demographics of the participants. Then, the next component includes the self-evaluated soft skills of pre-service teachers. Three professors in the teacher education field and three research experts, who do not partake in the study, carry out the content validity. The content validation ascertains clear and experienced-based questions suited to the participants. It also ensures that the respondent does not find difficulty in answering the questionnaire. The questionnaire consists of a 5-point Likert scale with 5 as "Very True of Me" and with 1 as "Not True of Me" to self-evaluate their soft skills geared toward practice teaching. The instrument also underwent a reliability test with a Cronbach alpha value of .91, which means highly reliable.

The qualitative part of the study for the pre-service teachers uses an unrestricted essay for contextual analysis regarding the most acquired soft skills of pre-service teachers, which they can use in practice teaching. This part is the last part of the instrument for pre-service teachers. The researchers consulted experts regarding the validity of the question of the essay.

For the quantitative part of the instrument for the CTs, a parallel survey questionnaire, like that of the pre-service teachers, was used. It determines the soft skills of pre-service teachers from the observations and documentation of the CTs. Content validity was also conducted while for the reliability of the instrument, a Cronbach alpha value of .88, which means that it has good reliability. For the qualitative part for the CTs, an unstructured interview was conducted to twenty-seven selected CTs regarding the observed soft skills of pre-service teachers that they are mentoring. Figure 1 shows the flow of data gathering.

As seen in Figure 1, before the deployment of the pre-service teachers, a survey on their soft skills with the unrestricted essay was conducted through Google forms. A communication letter for permission and approval passes through channels for proper documentation and protocols before the conduct of the survey.

After this, the pre-service teachers undergo internship or practice teaching to the assigned cooperating schools. Each pre-service teacher was assigned to a cooperating teacher who mentors them. The university professors monitor the pre-service teachers in the middle of the duration of the internship. It was executed through a memorandum of an agreement forged between the university and the cooperating schools on monitoring and evaluation of the internship of the pre-service teachers. The CTs give their feedback through the survey questionnaire and the unstructured interview, which lasted for a minimum of 30 minutes to a maximum of 1 hour at the final demonstration teaching of the pre-service teachers.

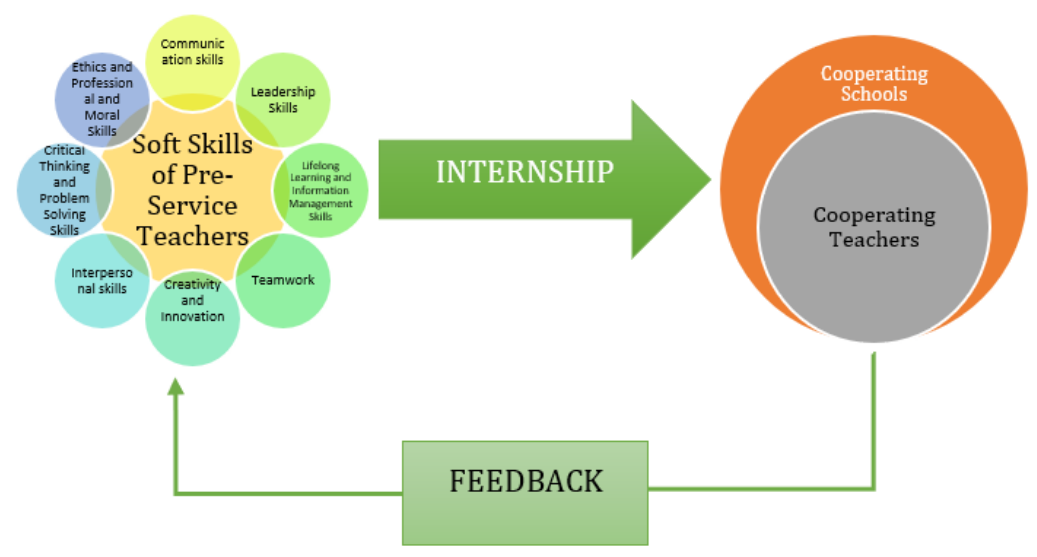

Figure 1. The framework of the study

\section{Data Analysis}

Descriptive statistics were utilized through average weighted means and standard deviations using SPSS version 21.0. The data scoring, in the case of pre-service teachers, is reported as 4.20-5.00 "Very Highly 
Acquired (VHA)"; 3.40-4.19 "Highly Acquired (HA)"; 2.60-3.39 "Moderately Acquired(MA)"; 1.80-2.59 "Slightly Acquired (FA)"; and 1.00-1.79 "Not Acquired(NA)" Inferential statistics supported the result. Whereas, the data scoring, in the case of CTs, is reported as 4.20-5.00 "Very Highly Observed (VHO)"; 3.40-4.19 "Highly Observed (HO)"; 2.60-3.39 "Moderately Observed(MO)"; 1.80-2.59 "Slightly Observed(SO)"; and 1.00-1.79 "Not Observed(NO)."

The statistical tool used to elicit data on the significant difference between the self-evaluated soft skills of the pre-service teachers and the observed soft skills of pre-service teachers by the cooperating teachers is the Wilcoxon matched-pairs signed-rank test.

The interview recording was transcribed and coded deductively, while the unrestricted essays are compiled and analyzed. The researchers also used the side-by-side comparison of discussion through reporting the quantitative statistical result and then discuss the qualitative findings that either confirm or disconfirm the statistical results.

\section{RESULTS}

In Table 1, the self-evaluated soft skills acquired by pre-service teachers have an overall mean of 4.19 $(S D=.60)$ - "Highly Acquired" or "HA." Specifically, Teamwork and Interpersonal soft skills are the topmost acquired self-evaluated soft skills by pre-service teachers with a mean of $4.44(S D=.53)$, "VHA," and 4.38 $(S D=.52)$, "VHA," respectively. Leadership skills $(M=4.24, S D=.64)$ and Ethics and Professional and Moral Skills $(M=4.22, \mathrm{SD}=.58)$ are also self-evaluated as "VHA" by pre-service teachers. Whereas, the item "creativity and innovation" has the lowest mean of $3.87(S D=.72)$, which still has a descriptive rating of "HA."

Contextual analysis of the essays of the participants supports these results. The emerging themes are "interpersonal," "teamwork," and "communication" as the most common soft skills acquired by preservice teachers. As to interpersonal skills, Pre-service teacher 3 told that:

"For me, the best soft skill that we must have is interpersonal, because as a future educator, you need to interact and socialize with other people; you need to adapt their culture or tradition to fit in that group of people. Because Interpersonal skill does not only talk about how you interact with people around your circle, but this is on how you understand, cope, and respect their different perspectives. As a future [teacher], we need this interpersonal skill so that we can face every individual with confidence."

Furthermore, according to Pre-service teacher 28:

"I have interpersonal skills because I use them when communicating and collaborating with others. Without them, my life is inherently more challenging."

Concerning teamwork, Pre-service teacher 42 chided that:

"I have teamwork for collaborating activity. It is the way to push on innovation or to resolve something going to happen or challenges that have in one situation. This soft skill involves togetherness to reach the abilities to work on their activities."

Finally, concerning communication, when Pre-service teacher 63 was asked about it, he said that:

"I think it's communication skills because I can clearly express myself positively and clearly."

On the other hand, CT observed the soft skills of the pre-service teachers and showed a mean of $4.01(S D=.64)$ or "Highly Observed" or "HO" as its descriptive rating in Table 1. Moreover, on the specific items on soft skills observed by CT, the item "Leadership Skills" has a mean of $4.46(S D=.45)$, which transmutes to "VHO." Similarly, the researchers discovered that Lifelong Learning and Information Management Skill $(M=4.45, S D=.48)$ is "VHO" in the pre-service teachers by their CT during the internship, whereas, Teamwork $(M=4.37, S D=.47)$ and Ethics and Professional and Moral Skills $(M=4.31, S D=.49)$ are both "VHO" in the pre-service teachers. Communication Skills $(M=3.84, S D=.73)$; Creativity and Innovation, $(M=3.78, S D=.79)$; and Critical Thinking; and Problem-Solving Skills $(M=3.51, S D=.75)$ were reported to be "HO" as feedbacked by CTs.

On the contrary, the item "Interpersonal" has a mean of $3.40(S D=.96)$ and a descriptive rating of "MO." It was the least observed soft skills of pre-service teachers by CT.

The supporting statements based on emerging themes such as "leadership" and "teamwork" can be found below. As to leadership skills, CT participant 4 told that:

"They knew how to lead and organize activities in the school such as Foundation Day, with very minimal supervision from us."

Moreover, CT participant 11 said:

"They are excellent in managing their classes, and they know how to direct school activities."

With regard to teamwork, CT participant 7 and 18 told that:

"They are helpful to one another. No one is left behind in times of work; they all work together and collaborate". 
"Before they had their final demo teaching, they helped each other in preparing their IMs and lesson plans. It was almost nighttime when they went home, for they had to help a comrade who has not prepared well for his final demo."

With the abovementioned results, CT's feedback jives with the pre-service teachers' selfevaluation of their acquired soft skills. In contrast, however, while pre-service teachers believe that they highly acquired interpersonal skills, it is the weakest soft skill observed by CT.

Table 1: Perceived soft skills acquired by pre-service teachers and soft skills observed by cooperating teachers (CT)

\begin{tabular}{|l|c|c|c|c|c|c|}
\hline \multicolumn{1}{|c|}{ Soft Skills } & \multicolumn{2}{|c|}{ Pre-service Teachers(N=147) } & \multicolumn{2}{c|}{ Cooperating Teachers(N=125) } \\
\hline & Mean & $\begin{array}{c}\text { Descriptive } \\
\text { Rating }\end{array}$ & $\begin{array}{c}\text { Std. } \\
\text { Deviation }\end{array}$ & Mean & $\begin{array}{c}\text { Descriptive } \\
\text { Rating }\end{array}$ & $\begin{array}{c}\text { Std. } \\
\text { Deviation }\end{array}$ \\
\hline Communication Skills & 4.08 & $H A$ & .59 & 3.84 & $H O$ & .73 \\
\hline $\begin{array}{l}\text { Critical Thinking and } \\
\text { Problem-Solving Skills }\end{array}$ & 4.04 & $H A$ & .62 & 3.51 & $H O$ & .75 \\
\hline $\begin{array}{l}\text { Ethics and Professional and } \\
\text { Moral Skills }\end{array}$ & 4.22 & $V H A$ & .58 & 4.31 & $V H O$ & .49 \\
\hline Leadership Skills & 4.24 & $V H A$ & .64 & 4.46 & $V H O$ & .45 \\
\hline $\begin{array}{l}\text { Lifelong Learning and } \\
\text { Information Management } \\
\text { Skills }\end{array}$ & 4.21 & $V H A$ & .56 & 4.45 & $V H O$ & .48 \\
\hline Teamwork & 4.44 & $V H A$ & .53 & 4.37 & $V H O$ & .47 \\
\hline Creativity and Innovation & 3.87 & HA & .72 & 3.78 & $H O$ & .79 \\
\hline Interpersonal & 4.38 & VHA & .52 & 3.40 & MO & .96 \\
\hline \multicolumn{1}{|c|}{ OVERALL } & $\mathbf{4 . 1 9}$ & HA & .60 & $\mathbf{4 . 0 1}$ & HO & .64 \\
\hline
\end{tabular}

Legend:

\begin{tabular}{|l|l|l|l|l|}
\hline $\begin{array}{l}\text { Weighted } \\
\text { Mean }\end{array}$ & Description & $\begin{array}{l}\text { Weighted } \\
\text { Mean }\end{array}$ & Description \\
\hline $4.20-5.00$ & $\begin{array}{l}\text { Very Highly } \\
\text { Acquired(VHA) }\end{array}$ & & $4.20-5.00$ & $\begin{array}{l}\text { Very Highly } \\
\text { Observed (VHO) }\end{array}$ \\
\hline $3.40-4.19$ & Highly Acquired(HA) & & $3.40-4.19$ & $\begin{array}{l}\text { Highly Observed } \\
\text { (HO) }\end{array}$ \\
\hline $2.60-3.39$ & $\begin{array}{l}\text { Moderately } \\
\text { Acquired(MA) }\end{array}$ & & $2.60-3.39$ & $\begin{array}{l}\text { Moderately } \\
\text { Observed(MO) }\end{array}$ \\
\hline $1.80-2.59$ & $\begin{array}{l}\text { Slightly Acquired } \\
\text { FA) }\end{array}$ & & $1.80-2.59$ & $\begin{array}{l}\text { Slightly } \\
\text { Observed(SO) }\end{array}$ \\
\hline $1.00-1.79$ & Not Acquired(NA) & $1.00-1.79$ & Not Observed(NO) \\
\hline
\end{tabular}

The difference between the self-evaluated soft skills of pre-service teachers and the soft skills of pre-service teachers observed by cooperating teachers

A Wilcoxon matched-pairs signed-rank test was carried out to evaluate the significant difference between the results of the perceived acquired soft skills of pre-service teachers and the soft skills of preservice teachers observed by CT. Through the Wilcoxon test, it determined whether there was a discrepancy of skills acquired in the undergraduate program and skills observed in the internship.

The summary of the Wilcoxon S-R Test - Ranks of each set of soft skills was presented in Table 2, whereas Table 3 summarized the test statistics of each set of soft skills using the Wilcoxon signed-rank test.

The results of the analysis asserted that there was a significant difference between perceived acquired communication skills of pre-service teachers and the observed communication skills of preservice teachers from the perspectives of CT, $T=3105, Z=-2.924, p<.01, r=.24$. The mean rank supportive of pre-service teachers' self-evaluation of their communication skills was 68.35, while the mean rank affirmative of cooperating teacher's report of pre-service teachers' communication skills was 63.37 . 
Table 2: Wilcoxon S-R Test - Ranks Table Output of Each Set of Soft Skills

\begin{tabular}{|c|c|c|c|c|}
\hline \multicolumn{5}{|c|}{ Ranks } \\
\hline & & $\mathrm{N}$ & Mean Rank & Sum of Ranks \\
\hline \multirow{4}{*}{$\begin{array}{l}\text { Communication Skills CT - } \\
\text { Communication Skills PT }\end{array}$} & Negative Ranks & $83^{a}$ & 68.35 & 5673.00 \\
\hline & Positive Ranks & $49^{b}$ & 63.37 & 3105.00 \\
\hline & Ties & $15^{c}$ & & \\
\hline & Total & 147 & & \\
\hline \multirow{4}{*}{$\begin{array}{l}\text { Critical Thinking Skills CT - } \\
\text { Critical Thinking Skills PT }\end{array}$} & Negative Ranks & $92^{d}$ & 76.08 & 6999.50 \\
\hline & Positive Ranks & $41^{\mathrm{e}}$ & 46.62 & 1911.50 \\
\hline & Ties & $14^{\mathrm{f}}$ & & \\
\hline & Total & 147 & & \\
\hline \multirow{4}{*}{$\begin{array}{l}\text { Ethics and Professional and } \\
\text { Moral Skills CT - Ethics and } \\
\text { Professional Moral Skills PT }\end{array}$} & Negative Ranks & $57 \mathrm{~g}$ & 59.76 & 3406.50 \\
\hline & Positive Ranks & $68^{\mathrm{h}}$ & 65.71 & 4468.50 \\
\hline & Ties & $22^{i}$ & & \\
\hline & Total & 147 & & \\
\hline \multirow{4}{*}{$\begin{array}{l}\text { Leadership Skills CT - } \\
\text { Leadership Skills PT }\end{array}$} & Negative Ranks & $57^{j}$ & 65.93 & 3758.00 \\
\hline & Positive Ranks & $74 \mathrm{k}$ & 66.05 & 4888.00 \\
\hline & \begin{tabular}{|l|} 
Ties \\
\end{tabular} & $16^{1}$ & & \\
\hline & Total & 147 & & \\
\hline \multirow{4}{*}{$\begin{array}{l}\text { Lifelong Learning and } \\
\text { Management of Information CT } \\
\text { - Lifelong Learning and } \\
\text { Management of Information PT }\end{array}$} & Negative Ranks & $49^{m}$ & 63.02 & 3088.00 \\
\hline & Positive Ranks & $82^{n}$ & 67.78 & 5558.00 \\
\hline & Ties & $16^{\circ}$ & & \\
\hline & \begin{tabular}{|l|} 
Total \\
\end{tabular} & 147 & & \\
\hline \multirow{4}{*}{ Teamwork CT - Teamwork PT } & Negative Ranks & $72 \mathrm{p}$ & 65.90 & 4744.50 \\
\hline & Positive Ranks & $58^{q}$ & 65.01 & 3770.50 \\
\hline & \begin{tabular}{|l|} 
Ties \\
\end{tabular} & $17^{r}$ & & \\
\hline & Total & 147 & & \\
\hline \multirow{4}{*}{$\begin{array}{l}\text { Creativity and Innovation Skills } \\
\text { CT - Creativity and Innovation } \\
\text { Skills PT }\end{array}$} & Negative Ranks & $76^{s}$ & 71.88 & 5463.00 \\
\hline & Positive Ranks & $64^{\mathrm{t}}$ & 68.86 & 4407.00 \\
\hline & \begin{tabular}{|l|} 
Ties \\
\end{tabular} & $7 \mathrm{u}$ & & \\
\hline & Total & 147 & & \\
\hline \multirow{4}{*}{$\begin{array}{l}\text { Interpersonal Skills CT - } \\
\text { Interpersonal Skills PT }\end{array}$} & Negative Ranks & $115^{v}$ & 75.45 & 8677.00 \\
\hline & \begin{tabular}{|l|} 
Positive Ranks \\
\end{tabular} & $21^{w}$ & 30.43 & 639.00 \\
\hline & \begin{tabular}{|l|} 
Ties \\
\end{tabular} & $11^{\mathrm{x}}$ & & \\
\hline & Total & 147 & & \\
\hline \multicolumn{5}{|c|}{ a. CommunicationSkillsCT < CommunicationSkillsPT } \\
\hline \multicolumn{5}{|c|}{ b. CommunicationSkillsCT > CommunicationSkillsPT } \\
\hline \multicolumn{5}{|c|}{ c. CommunicationSkillsCT = CommunicationSkillsPT } \\
\hline \multicolumn{5}{|c|}{ d. CriticalThinkingSkillsCT $<$ CriticalThinkingSkillsPT } \\
\hline \multicolumn{5}{|c|}{ e. CriticalThinkingSkillsCT > CriticalThinkingSkillsPT } \\
\hline \multicolumn{5}{|c|}{ f. CriticalThinkingSkillsCT = CriticalThinkingSkillsPT } \\
\hline \multicolumn{5}{|c|}{ g. EthicsProfessional_MoralSkillsCT $<$ EthicsProfessional_MoralSkillsPT } \\
\hline \multicolumn{5}{|c|}{ h. EthicsProfessional_MoralSkillsCT > EthicsProfessional_MoralSkillsPT } \\
\hline \multicolumn{5}{|c|}{ i. EthicsProfessional_MoralSkillsCT = EthicsProfessional_MoralSkillsPT } \\
\hline \multicolumn{5}{|c|}{ j. LeadershipSkillsCT < LeadershipSkillsPT } \\
\hline k. LeadershipSkillsCT > Leaders & iipSkillsPT & & & \\
\hline l. LeadershipSkillsCT = Leadersh & ipSkillsPT & & & \\
\hline m. LifelongLearning_Manageme & tofInformationCT & ngLea & Managemen & formationPT \\
\hline n. LifelongLearning_Managemen & tofInformationCT & ngLear & Management & formationPT \\
\hline o. LifelongLearning_Managemen & tofInformationCT & ngLear & Management & formationPT \\
\hline p. TeamworkCT < TeamworkPT & & & & \\
\hline q. TeamworkCT > TeamworkPT & & & & \\
\hline r. TeamworkCT = TeamworkPT & & & & \\
\hline s. CreativityandInnovationSkills & $\mathrm{CT}<$ Creativityand & ionSkil & & \\
\hline t. CreativityandInnovationSkills & $\mathrm{T}>$ Creativityand & ionSkil & & \\
\hline u. CreativityandInnovationSkills & $\mathrm{CT}=$ Creativityand & tionSki & & \\
\hline
\end{tabular}




\begin{tabular}{|l|}
\hline v. InterpersonalSkillsCT $<$ InterpersonalSkillsPT \\
\hline w. InterpersonalSkillsCT $>$ InterpersonalSkillsPT \\
\hline x. InterpersonalSkillsCT $=$ InterpersonalSkillsPT \\
\hline
\end{tabular}

Table 3: Significant Difference between the perceived acquired soft skills of pre-service teachers and the observed soft skills of pre-service teachers by the cooperating teachers

\begin{tabular}{|l|c|c|c|}
\hline \multicolumn{1}{|c|}{ Soft Skills } & $Z$ & $\begin{array}{l}\text { Asymp. Sig. } \\
\text { (2- Tailed) }\end{array}$ & $r$ \\
\hline Communication Skills & $-2.924^{\mathrm{b} *}$ & .003 & .24 \\
\hline Critical Thinking and Problem Solving Skills & $-5.723^{\mathrm{b} * *}$ & .000 & .47 \\
\hline Ethics and Professional and Moral Skills & $-1.312^{\mathrm{c}}$ & .189 & .11 \\
\hline Leadership Skills & $-1.302^{\mathrm{c}}$ & .193 & .11 \\
\hline $\begin{array}{l}\text { Lifelong Learning and Information } \\
\text { Management Skills }\end{array}$ & $-2.846^{*}$ & .004 & .24 \\
\hline Teamwork & $-1.136^{\mathrm{b}}$ & .257 & .09 \\
\hline Creativity and Innovation & $-1.100^{\mathrm{b}}$ & .271 & .09 \\
\hline Interpersonal & $-8.737^{\mathrm{b} * *}$ & .000 & .72 \\
\hline
\end{tabular}

* Significant at 0.01 level(2-tailed)

** Significant at 0.001 level(2-tailed)

b. Based on positive ranks

c. Based on negative ranks

The results also confirmed a significant difference between Critical Thinking Skills self-perceived by pre-service teachers and the report provided by the CTs, $T=1911.50, Z=-5.723, p<.001, r=.47$. Specifically, the results indicate significant differential concern for pre-service teachers' self-selfevaluation of their critical thinking with a mean rank of 76.08 versus CTs' report of the pre-service teachers' actual critical thinking skills with a mean rank of 46.62 .

Moreover, the self-evaluation of pre-service teachers and the report of the CTs of their actual Lifelong Learning and Management of Information skills were compared. On the average, the selfevaluation of the pre-service teachers of their acquired lifelong learning and management of information skills is lower with a mean rank of 63.02 than the report of the CTs of their lifelong learning and management of information actual skills with a mean rank of 67.78. A Wilcoxon signed-ranked test pointed out that this difference was statistically significant, $T=5558, Z=-2.846, \mathrm{p}<.01, r=.24$.

In the same instance, a significant difference existed between the self-evaluation of the pre-service teachers and the report of the CTs of their actual Interpersonal skills, $T=639, Z=-8.737, \mathrm{p}<.001, r=.72$. The mean rank in accord of pre-service teachers' self-evaluation of their interpersonal skills was 75.45, while the mean rank in accord of cooperating teacher's report of pre-service teachers' interpersonal skills was 30.43. The following extracts are the comparison of the self-evaluation of pre-service teachers and the observation of CTs on soft skills.

In terms of Communication skills, pre-service teacher 16 perceived that:

"As a Pre-service teacher, I must have good communication skills and be a good listener. Being a good communicator, I can use it when I'm going to apply for a job. For example, in an interview, I can employ this skill. In communicating with others, it is important that you're a good listener who listens to the suggestions or corrections given to you. I know there are many soft skills that a teacher must have even though these two skills are the only ones I have at present, I'll do my best to learn so that in the future I can apply them in my teaching profession."

On the contrary, CT 12 quipped:

"He has a limited vocabulary and cannot express himself in Mother Tongue, much more in the English medium of instruction and conversational settings. He has faulty grammar in English that delimits him to talk and communicate, especially for subjects that use English as a medium of instruction."

With regard to Critical Thinking and Problem Solving, Pre-service teacher 19 believed that:

"For me, I have the Critical thinking and problem-solving skills because as a future teacher, I must be a critical thinker so that students will be able to practice it too. With that, they can at least think like the way you do, which shall be helpful in solving daily problems in school and everyday life".

On the other hand, CT participant 22 remarked that:

"Sometimes, I doubt her capacity and her common sense because she does not think critically in dealing with the given tasks; instead, she always asks me on what to do next even though the task 
is simple. She does not also know how to solve problems arising from student to student bullying and fighting inside the classroom. She would always refer them to me instead of acting on it first".

Moreover, regarding the lifelong learning and information management skills, the following extracts show differences between pre-service teachers' self-evaluation and of the CTs' observation. Pre-service teacher 90 said that:

"As a pre-service teacher, I think the best skill that I have is interpersonal skills because I know that I am a more sociable person, and I like to communicate with the people around me."

To this, CT Participant 5 commends more the pre-service teachers with the following statement:

"I really love how passionate and enthusiastic they are to learn from us- their cooperating teachers and from administrators. I see their eagerness to pick up more by not missing any Learning Action Cell (LAC) session in the school. They are not afraid to try new methodologies and techniques. Rather, they apply these learning and information in their own classes... and boom! There demonstration teachings are really amazing and impressive."

Finally, regarding interpersonal skills, the following extracts show differences between pre-service teachers' self-evaluation and of the CTs' observation. Pre-service teacher 90 said that:

"As a pre-service teacher, my skill is to learn from everything and everyone outside the four corners of the classroom, and make this learning into a fruitful armor in improving my career as a teacher in the future."

Meanwhile, CT Participant 9 and 15 contradicted that of the pre-service teacher's statement:

"Most of them are shy and timid. They seldom interact, and most of the time, they isolate themselves."

"They are silent and do not voice out their problems encountered to the students and their cooperating teachers."

On the other hand, the Wilcoxon signed-rank test did not elicit a significant difference present between the self-evaluation of the pre-service teachers and the report of the CTs of their actual Ethics and Professional and Moral Skills ( $T=4468.50, Z=-1.312, p>.05, r=.119$ ); Leadership Skills ( $T=4888, Z=-$ 1.302, $p>.05, r=.11)$; Teamwork( $T=3770.50, Z=-1.136, p>.05, r=.09) ;$ and Creativity and Innovation ( $T=4407, Z=-1.100, p>.05, r=.09)$.

\section{DISCUSSION AND CONCLUSIONS}

The school-to-work transition in understanding the soft skills of the pre-service teachers molded by universities and the feedback of the industry is highlighted in this study. Based on the overall selfevaluated results, pre-service teachers are equipped with soft skills which they used in their internship. This result attested that pre-service teachers obtained social and behavioral skills fundamental to their practice teaching (internship) with consideration to their working environment. This result is contrary to the study conducted by Yoke \& Ngang (2017) that students do not put sufficient effort into all the essential soft skill components.

This finding also shows that the university has impacted their soft skills to become ready in the real setting of work. This is the same as the study of Yoke \& Ngang (2017) that soft skill development is reliant on the teacher's initiative to effect its methodology. It also indicates a continuum progression of soft skills from their undergraduate courses to their internship. This statement is parallel to the study of Waterhouse \& Virgona (2004) that soft skills develop continuously. Hence, soft skills gradually are enhanced to being acquired into highly acquired or from novice to expert through experiences and probably adapt to the soft skills that the working environment, such as the cooperating schools, promotes.

Particularly on the self-evaluated soft skills made by pre-service teachers, Teamwork, Interpersonal Skills, Leadership Skills, and Ethics and Professional and Moral Skills are the dominants of these soft skills. These data imply that pre-service teachers, in their self-evaluation of their soft skills, have acquired the ability to deal with others individually or in groups, whether in social and behavioral situations involving students, parents, faculty, or administrators in their internship. The result also implies that they know how to lead activities and groups of people with ethical and moral considerations and are guided with values-driven actions. The unrestricted essays indicated that pre-service teachers are aware of the diversity of culture, traditions, language, and personality of the key players in the teaching environment. Thus, they are crucial for how they socialize and show fairness and judgment to people around them. Despite that the essays emphasize communication skills, it did not show a high evaluation of the survey.

As regard Creativity and Innovation, the self-evaluation of pre-service teachers on this soft skill undermines half-baked. It implies that pre-service teachers have not fully discovered their creativity in all 
aspects yet, lack elaboration and originality, difficulty in transforming the process into valuable outputs. But through the internship, they are in the process of acquiring or benchmarking from their seasoned CT. This result is inconsistent with the research study of Nakano \& Wechsler (2018)that emphasizes

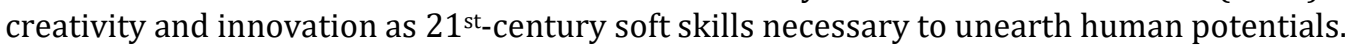

Following the findings on the feedback of the CTs on the soft skills of the pre-service teachers, it appeared that Leadership Skills, Lifelong Learning and Information Management Skills, Teamwork, and Ethics and Professional and Moral Skills are the most active soft skills observed. It implies that preservice teachers know how to support learning continuously and cope with adversities in their life as preservice teachers. It can also be mirrored that pre-service teachers have a vision of their capacity to lead a school event or a simple activity inside and outside the classroom and curriculum through cooperative work. The pre-service teachers are also guided with a high standard of morals toward professional practice. This statement is congruent with the quantitative result of the study of Ngang et al. (2015) that school administrators expect Ethics and Professional and Moral Skills to be highly present to a teacher. The CTs interview highlighted that pre-service teachers showed a passion for becoming better in their craft by learning from their mentors proactively and continuously with a sense of cooperation and ethics. This passion is seen in the Learning Action Cell (LAC) sessions of CT attended weekly by the pre-service teachers in which they convene, share their expertise, and help fellow teachers and pre-service teachers regarding the problems they encounter in their classroom. CTs also confirm that the pre-service teachers have the innate capability to lead, influence others, align the efforts of others, and build commitment from people at all levels through teamwork.

Furthermore, Interpersonal skill was adjudged by the CTs as the weakest soft skills of the preservice teachers. This data implies that pre-service teachers are roughly adapting and adjusting to their new environment; thus, they tend to isolate themselves. This observation of pre-service teachers made an impression on who they are in the school. According to Dabke (2015), interpersonal skills positively impact an intern in a particular organization. However, interpersonal skills are also learnable. This statement is supported by the study of Rekha \& Ganesh (2012)that concluded that mentees learned fundamental soft skills such as interpersonal and leadership through a mentorship program. Whereas, Klein (2009) has indicated the existence of interpersonal skills and leadership skills as the topmost preferred soft skills.

On a grander note, the results indicate that there exists a significant difference in the pre-service teachers' self-evaluation of their acquired soft skills and the feedback of CTs. Specifically, Interpersonal Skills, Communication Skills, and Critical Thinking and Problem-Solving Skills manifest this difference between pre-service teachers and CTs. These results imply a mismatch of how pre-service teachers perceived their soft skills in these areas compared to the observation of the CT; thus, a potential barrier to pre-service teachers to perform better in their internship is at stake. These three soft skills are essential in the workstation, yet, it has specific issues as seen in the placement of the pre-service teachers, thus, may cause future setbacks to these pre-service teachers when they are hired when not given attention to be improved. Francis (2017) articulated that some university-level graduates lack soft skills such as communication skills, problem-solving skills, creative and critical thinking, and interpersonal skills, which are necessary to the labor market. He further argued that while academic, technical skills are mandatory, when a graduate lacks social and soft skills such as communication skills, problem-solving skills, creative and critical thinking, and interpersonal skills, employers may not take them on. Also, Levasseur (2013) concluded that many college graduates lack training on soft skills even though employers prefer hirees with strong soft skills. Among these soft skills that lack training is communication skills, problem-solving skills, creative and critical thinking skills, and interpersonal skills. To these, a graduate is expected to be well-versed in English and Mother Tongue languages, become an objective analyst of a problem with an unorthodox solution, and be an effective and efficient contact with others. Furthermore, in the study of Ngang et al. (2015), it strongly emphasizes that there was not enough training given to would-be teachers in their undergraduate programs about soft skills.

Whereas, pre-service teachers underestimated their lifelong learning and management of information skills as compared to more active skills being observed by CTs. It indicates that pre-service teachers are adaptable in interweaving new and current trends with previous information and learning in making the quality of their life or career better.

This research highlights the gaps in some soft skills from university to industry. Nida'a \& Worley (2018) revealed that gaps are evident in the soft skills for the occupation of college graduates and their school's conveyed soft skills to them. This gap was observed in the changing landscape of the labor marketplace. Specific soft skills are mismatched to the training of the graduates, which needs enhancement throughout their degree program (Pillai et al., 2012). 
The findings also affirm and validate the attainment of the philosophy of the university on providing total human development to every graduate, including soft skills, which are acknowledged by the stakeholders such as CTs and cooperating schools. These soft skills (Ethics and Professional and Moral Skills; Leadership Skills; Teamwork; and Creativity and Innovation) are comparable from schoolto-work transitions. These results assure that pre-service teachers entering the teaching profession are equipped with necessary soft skills and that it gives confidence to the cooperating schools absorbing them in the future to turn these soft skills as an asset to the school. Employers indicate that the success rate in getting a job or in a business venture is determined by the holistic skills acquired rather than only academic credentials and technical skills (Beard et al., 2008; Duncan \& Dunifon, 1998; Gibson \& Sodeman, 2014; John, 2009; Schulz, 2008) while soft skills as invaluable to an organization (Wilhelm, 2004).

Given the findings, this research acclaims that the university may employ training for enhancing soft skills by following different strategies of instruction. Also, the institution may create some specific, practical subjects and offer some guidance courses for graduates to guide them to establish a correct employment concept and accurate positioning in the future. A job placement office will be a great help to this endeavor. Before an internship starts, a job placement seminar/ training on the different soft skills may be forwarded to refresh the pre-service teachers of the preferred soft skills of the cooperating schools. Further, the curriculum may encourage communicative competence, creativity, curiosity, realworld problem-solving skills, and interpersonal skills that would lead to students' holistic development. Also, a mechanism may be provided to review students about what to obtain from college/higher education not only in terms of skills and in terms of technical expertise on their chosen degrees but also of general life skills and soft skills. These suggestions backed up the study of Eisner (2010) on relevant and timely competencies in the modern age, which is desirable to have by new college graduates amidst uncertainties of the current and future labor market.

Since Communication, Critical Thinking and Problem-solving skills and Interpersonal skills have significant differences between the two participants, an assessment of whether the employer's preference of soft skills matches teaching modalities may be made to avoid mismatches and to fit with the labor market.

Further studies may be conducted as to the experimental research on the effectiveness of training on soft skills, curriculum revision, or mentoring from cooperating teachers and other variables to attest soft skills' viability in the academic community.

Finally, it cannot be denied that soft skills are vital, and one of the sine qua non in the realization of a better future of the academic community.

\section{REFERENCES}

Andrews, J., \& Higson, H. (2008). Graduate employability,'soft skills' versus 'hard'business knowledge: A European study. Higher Education in Europe, 33(4), 411-422.

Bailly, F., \& Léné, A. (2013). The personification of the service labour process and the rise of soft skills: A $\begin{array}{llll}\text { French } & \text { case } & \text { Employee } & \text { 79-97. }\end{array}$ https://doi.org/10.1108/01425451311279429

Beard, D., Schwieger, D., \& Surendran, K. (2008). Preparing the millennial generation for the work place: how can academia help? Proceedings of the 2008 ACM SIGMIS CPR Conference on Computer Personnel Doctoral Consortium and Research, 102-105.

Bee, O. K., \& Hie, T. S. (2015). Employers' emphasis on technical skills and soft skills in job advertisements. The English Teacher, 44(1), 1.

Casner-Lotto, J., \& Barrington, L. (2006). Are they really ready to work? Employers' perspectives on the basic knowledge and applied skills of new entrants to the 21st century US workforce. ERIC.

Creswell, J. W., \& Creswell, J. D. (2018). Research design: qualitative, quantitative, and mixed methods approaches.

Dabke, D. (2015). Soft skills as a predictor of perceived internship effectiveness and permanent placement opportunity. IUP Journal of Soft Skills, 9(4), 26.

Duncan, G. J., \& Dunifon, R. (1998). Soft-skills and long-run labor market success. Research in Labor Economics, 17.

Eisner, S. (2010). Grave New World? Workplace Skills For Todays College Graduates. American Journal of Business Education (AJBE), 3(9), 27-50.

Francis, K. (2017). Some tertiary graduates lacking 'soft skills' for employment. Jamaica Observer. http://www.jamaicaobserver.com/news/Some-tertiary-graduates-lacking--soft-skills--foremployment_90187

Gewertz, C. (2007). Soft skills in big demand. Education Week, 26(40), 25-27. 
Gibson, L. A., \& Sodeman, W. A. (2014). Millennials and technology: Addressing the communication gap in education and practice. Organization Development Journal, 32(4), 63-75.

Grugulis, I., \& Vincent, S. (2009). Whose skill is it anyway? 'soft'skills and polarization. Work, Employment and Society, 23(4), 597-615.

James, R. F., \& James, M. L. (2004). Teaching career and technical skills in a" mini" business world. Business Education Forum, 59, 39-41.

John, J. (2009). Study on the nature of impact of soft skills training programme on the soft skills development of management students. Pacific Business Review, 19-27.

Klein, C. (2009). What do we know about interpersonal skills? A meta-analytic examination of antecedents, outcomes, and the efficacy of training.

Levasseur, R. E. (2013). People skills: Developing soft skills-A change management perspective. Interfaces, 43(6), 566-571.

Meeks, G. A., \& Meeks, G. (2017). Critical Soft Skills to Achieve Success in the workplace This is to certify that the doctoral study by.

Mitchell, G. W., Skinner, L. B., \& White, B. J. (2010). Essential Soft Skills for Success in the Twenty-First Century Workforce as Perceived by Business Educators. Delta Pi Epsilon Journal, 52(1).

Morse, J. M. (1991). Approaches to qualitative-quantitative methodological triangulation. Nursing Research, 40(2), 120-123.

Nakano, T. de C., \& Wechsler, S. M. (2018). Creativity and innovation: Skills for the 21st Century. Estudos de Psicologia (Campinas), 35(3), 237-246.

Ngang, T. K., Yunus, H. M., \& Hashim, N. H. (2015). Soft skills integration in teaching professional training: Novice teachers' perspectives. Procedia-Social and Behavioral Sciences, 186, 835-840.

Nida'a, K. A., \& Worley, J. A. (2018). Leading toward new horizons with soft skills. On the Horizon.

Nikitina, L., \& Furuoka, F. (2012). Sharp focus on soft skills: a case study of Malaysian university students' educational expectations. Educational Research for Policy and Practice, 11(3), 207-224.

Osman, W. A. M., Girardi, A., \& Paull, M. (2012). Educator perceptions of soft skill development: An examination within the Malaysian public higher education sector. International Journal of Learning, 18(10), 49-62.

Pillai, S., Khan, M. H., Ibrahim, I. S., \& Raphael, S. (2012). Enhancing employability through industrial training in the Malaysian context. Higher Education, 63(2), 187-204.

Rao, M. S. (2018). Soft skills: Toward a sanctimonious discipline. On the Horizon.

Rekha, K. N., \& Ganesh, M. P. (2012). Do mentors learn by mentoring others? International Journal of Mentoring and Coaching in Education.

Robles, M. M. (2012). Executive perceptions of the top 10 soft skills needed in today's workplace. Business Communication Quarterly, 75(4), 453-465.

Schulz, B. (2008). The importance of soft skills: Education beyond academic knowledge.

Sharma, G., \& Sharma, P. (2010). Importance of Soft skills development in 21st century Curriculum. International Journal of Education \& Allied Sciences, 2(2).

Tran, T. T. (2013). Limitation on the development of skills in higher education in Vietnam. Higher Education, 65(5), 631-644.

Waterhouse, P. J., \& Virgona, C. (2004). Making experience work: Displaced workers provide new insights into generic skills. In Generic skills in vocational education and training: Research readings (pp. 109123). National Centre for Vocational Education Research.

Whitehurst, G. J. R. (2016). Grading soft skills: The Brookings soft skills report card. Evidence Speaks Reports, 2(4), 1-7.

Wilhelm, W. J. (2004). Determinants of moral reasoning: Academic factors, gender, richness of life experiences, and religious preferences. Delta Pi Epsilon Journal, 46(2), 105-123.

Yoke, T. C., \& Ngang, T. K. (2017). A study on soft skill development among final year diploma in business studies students. MOJEM: Malaysian Online Journal of Educational Management, 3(2), 32-50. 